- In general a significant decrease in marginal accuracy should be taken into consideration for partial coverage restorations after adhesive cementation.

- Adhesive luted partial coverage restorations appear to have a moderate increase in marginal gap width under masticatory aging.

- The introduced new preparation designs fulfil the technical demands to fabricate accurate fitting all ceramic partial coverage restorations.

\title{
Marginal adaptation of different types of all- ceramic partial coverage restorations after exposure to an artificial mouth
}

\author{
C. F. J. Stappert, ${ }^{1}$ N. Denner, ${ }^{2}$ T. Gerds ${ }^{3}$ and J. R. Strub ${ }^{4}$
}

\begin{abstract}
Objectives To determine the influence of the preparation design and the dimensions of all-ceramic partial coverage restorations (PCR) on the marginal accuracy before and after masticatory simulation.

Methods In this in vitro study 80 extracted human maxillary molars were restored with MOD inlay restorations and four different modified PCR restorations using a new press ceramic IPS e. max ${ }^{\circledR}$ Press (IPS e.max ${ }^{\circledR}$ Press VP 1989). The teeth were divided into five groups of 16 specimens each and prepared as follows: Group A received an MOD inlay preparation and Group B, C, D and E received modified PCR. The restorations were adhesively luted and exposed to a mastication simulator. The discrepancies of the marginal fit were examined on epoxy replicas before and after luting as well as after masticatory simulation at 200x magnification.

Results The mean (geometrical) [95\% confidence limits] marginal gap decreased from Group A to E before cementation (A-83[77-90] $\mu$ m, B68[65-70] $\mu \mathrm{m}, \mathrm{C}-59[55-64] \mu \mathrm{m}, \mathrm{D}-56[52-61] \mu \mathrm{m}, \mathrm{E}-50[45-55] \mu \mathrm{m})$. Group $A$ had significantly higher marginal gap values than group $B(p=0.017)$ and the other groups $(p<0.0001)$. After cementation the marginal accuracy was recorded as following: A-103[93-114] $\mu \mathrm{m}, \mathrm{B}-101$ [94108] $\mu \mathrm{m}, \mathrm{C}-93[89-98] \mu \mathrm{m}, \mathrm{D}-102[98-105] \mu \mathrm{m}$ and $\mathrm{E}-99[96-102] \mu \mathrm{m}$. Cementation increased the marginal gap in groups $B-E$ significantly $(p<0.00001)$, not significantly in group $A(p=0.059)$. Artificial aging $(A-$ 116[106-127] $\mu \mathrm{m}, \mathrm{B}-114[109-120] \mu \mathrm{m}, \mathrm{C}-106[103-110] \mu \mathrm{m}, \mathrm{D}-109[100-$ 118] $\mu \mathrm{m}$ and $\mathrm{E}-109$ [105-112] $\mu \mathrm{m})$ led to further significant decrease of marginal accuracy in Group B ( $p=0.029)$ and C $(p=0.026)$ only. After cementation and masticatory simulation of the ceramic restorations, the marginal gap values of Groups A, B, C, D and E did not significantly differ from each other $(p=1.00)$.
\end{abstract}

\footnotetext{
Senior Lecturer, Department of Prosthodontics, Albert-Ludwigs University, Freiburg, Germany and Department of Biomaterials and Biomimetics, New York University College of Dentistry, New York; ${ }^{2}$ Assistant Professor, Department of Prosthodontics, AlbertLudwigs-University, Freiburg, Germany ${ }^{3}$ Statistician, Department of Prosthodontics, Albert-Ludwigs University, Freiburg, Germany and Institute of Medical Biometrics and Medical Informatics, Albert-Ludwigs University, Freiburg, Germany ${ }^{4}$ Professor and Chairman, Department of Prosthodontics, Albert-Ludwigs University, Freiburg, Germany ${ }^{*}$ Correspondence to: Christian Stappert

Email:christian.stappert@nyu.edu
}

\section{Refereed paper}

Accepted 23 February 05

doi: $10.1038 /$ sj.bdj.4813036

๑ British Dental Journal 2005; 199: 779-783
Conclusions The result of this in vitro study showed that IPS e.max ${ }^{\circledR}$ Press can be used to fabricate all-ceramic inlays and PCR which meet the requirements in terms of a clinically acceptable marginal gap, irrespective of the preparation design used. However, the preparation design and dimensions of the restorations appeared to affect the initial marginal fit and flowing off of luting material during the cementation process. The factors responsible for these findings require further substantiation.

\section{INTRODUCTION}

The increasing awareness of aesthetics among patients and the growing concerns about amalgam restorations have led to an increase in the demand for alternative restorative materials in the posterior region as well as in the anterior region. Innovative dental ceramic systems provide such an alternative, because they can fulfil both functional and aesthetic requirements. These systems often involve new processing technologies and not all of them have yet been conclusively evaluated in terms of their clinical performance. Dental ceramic materials provide essential advantages over metal-ceramic and gold restorations. Not only do they offer superior aesthetic properties but also increased biocompatibility with tissues of the periodontium and pulp ${ }^{1}$ as well as a radiopacity which is similar to that of the natural tooth structure. At present, five different categories of fabrication techniques for creating all-ceramic partial crowns are known: form sintering (eg In-Ceram Spinell), casting (eg Dicor), heat pressing (eg IPS Empress), copy milling (eg Celay) and CAD/CAM processing (eg Cerec). The present study used a new all-ceramic material IPS e.max ${ }^{\circledR}$ Press. The material in question is a pressed ceramic from Ivoclar Vivadent AG, Schaan, Liechtenstein (IPS e.max ${ }^{\circledR}$ Press VP 1989). This pressed ceramic is intended to expand the range of indications of Empress ${ }^{\circledR} 2$ (Ivoclar Vivadent AG, Schaan, Liechtenstein). While it features similar physical properties as the latter, its translucency has been improved. The IPS e.max ${ }^{\circledR}$ Press system encompasses a high-stability framework material which consists of lithium disilicate (2 SiO-Li20). The restorations can be customised either by using a layering technique based on fluorapatite glass ceramic or by using the staining technique. The marginal fit of restorations is of particular interest and is a quality criteria for the evaluation of dental 


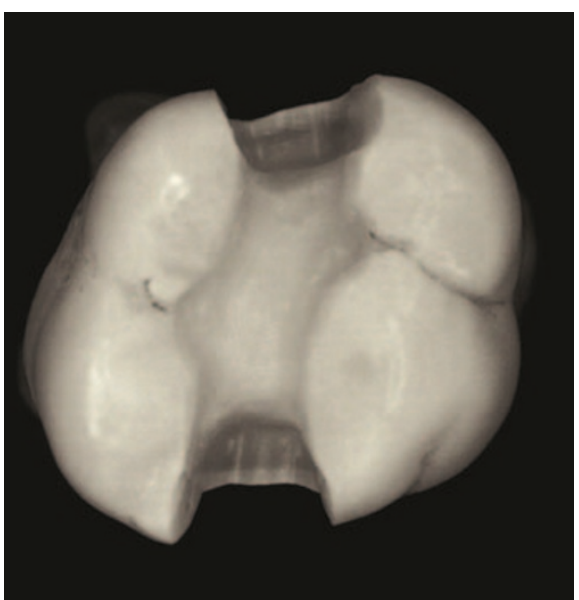

Fig. 1 Group A: Occlusal view

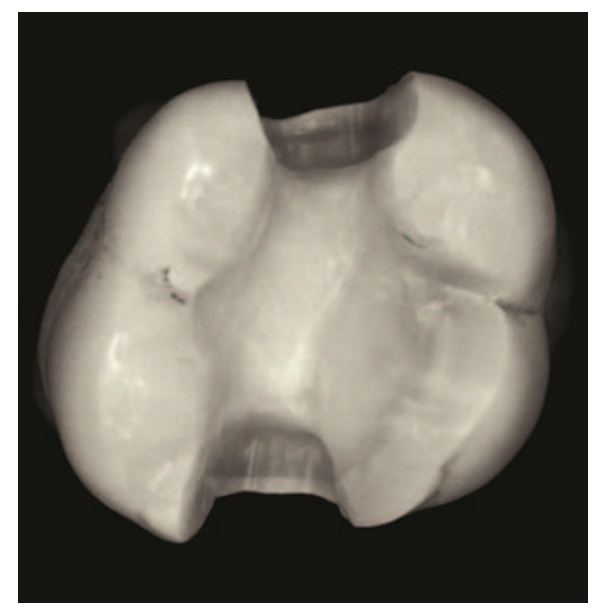

Fig. 2 Group B: Occlusal view

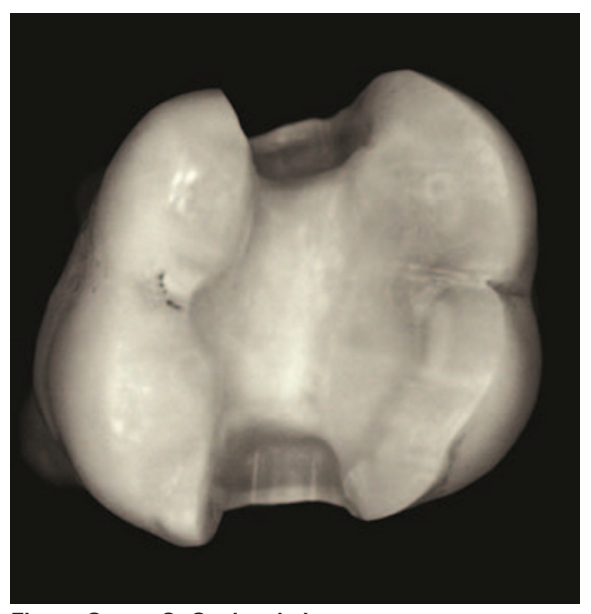

Fig. 3 Group C: Occlusal view

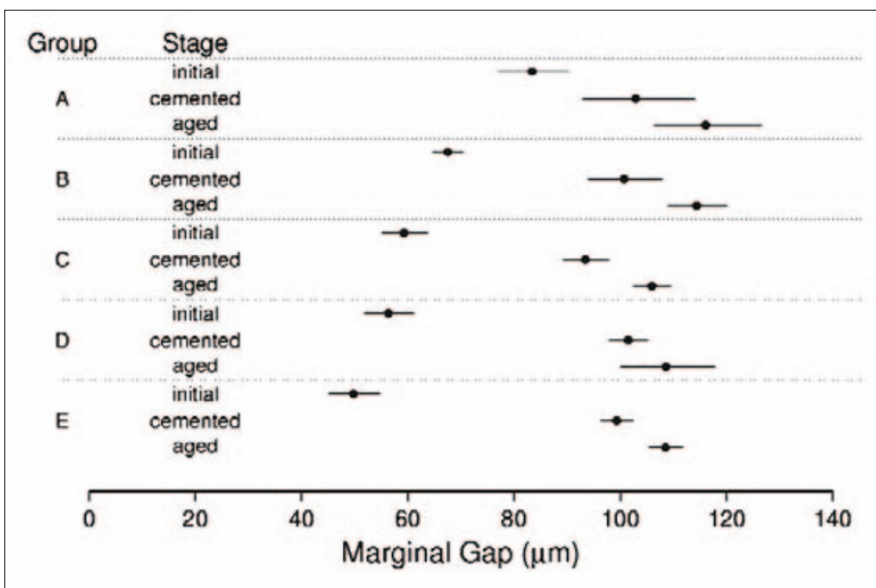

Fig. 7 Diagram of geometrical means after marginal gap analysis, before cementation (initial), after cementation (cemented) and after masticatory simulation (aged). Confidence intervals more to the left correspond to higher marginal accuracy. A: Inlay preparation, B: Reduction of one cusp, C:

Reduction of two cusps, D: Reduction of three cusps, E: Reduction of all cusps

\begin{tabular}{|c|c|c|c|}
\hline $\begin{array}{l}\text { Author/ } \\
\text { Year }\end{array}$ & Design & Material & Mean marginal gap \\
\hline $\mathrm{Hahn}^{25}$ & In vitro & $\begin{array}{l}\text { Dicor, Cerec and } \\
\text { Biodent inlays }\end{array}$ & $\begin{array}{l}\text { Dicor: approx. } 42 \mu \mathrm{m}, \text { occl. } 36 \mu \mathrm{m} \\
\text { Biodent: approx. } 42 \mu \mathrm{m}, \text { occl. } 18 \mu \mathrm{m} \\
\text { Cerec: approx. } 156 \mu \mathrm{m}, \text { occl. } 151 \mu \mathrm{m}\end{array}$ \\
\hline Siervo 26 & In vitro & $\begin{array}{l}\text { Celay } \\
\text { (direct/indirect } \\
\text { inlays) }\end{array}$ & $\begin{array}{l}\text { Direct technique: approx. } 67.81 \mu \mathrm{m} \text {; } \\
\text { occl. } 74.67 \mu \mathrm{m} \\
\text { Indirect technique: approx. } 86.28 \mu \mathrm{m} \text {; } \\
\text { occl. } 60.83 \mu \mathrm{m}\end{array}$ \\
\hline Siervo ${ }^{27}$ & In vitro & $\begin{array}{l}\text { Cerec, Celay and } \\
\text { Biodent inlays }\end{array}$ & $\begin{array}{l}\text { Cerec: between } 170 \mu \mathrm{m} \text { and } 200 \mu \mathrm{m} \\
\text { (depending on the software) } \\
\text { Celay: } 80 \mu \mathrm{m} \\
\text { Biodent: } 100 \mu \mathrm{m}\end{array}$ \\
\hline Gemalmaz $^{19}$ & In vitro & Ducera inlays & $\begin{array}{l}\text { Before cementation: } \\
\text { approx. } 105.6 \mu \mathrm{m} \text {, occl. } 71.83 \mu \mathrm{m} \\
\text { After cementation: } \\
\text { approx. }+6.94 \mu \mathrm{m} \text {, occl. }+23.25 \mu \mathrm{m}\end{array}$ \\
\hline Mörmann ${ }^{28}$ & In vitro & $\begin{array}{l}\text { Cerec } 1 \text { and } \\
\text { Cerec } 2 \text { with } \\
\text { Vita Mark II and } \\
\text { Dicor MGC }\end{array}$ & $\begin{array}{l}\text { The values measured for Cerec } 2 \text { were } \\
30 \% \text { lower than those measured for } \\
\text { Cerec } 1 \text {.The marginal gap width was } \\
56 \mu \mathrm{m} \pm 27 \mu \mathrm{m} \text {. }\end{array}$ \\
\hline Sturdevant ${ }^{29}$ & In vitro & $\begin{array}{l}\text { Cerec } 1 \text { and } \\
\text { Cerec } 2 \text { inlays }\end{array}$ & $\begin{array}{l}\text { Cerec 1: } \\
\text { occl. } 89 \pm 65 \mu \mathrm{m} \text {, approx. } 105 \pm 81 \mu \mathrm{m} \\
\text { Cerec 2: } \\
\text { occl. } 59 \pm 35 \mu \mathrm{m} \text {, approx. } 97 \pm 66 \mu \mathrm{m}\end{array}$ \\
\hline Denissen $^{12}$ & In vivo & $\begin{array}{l}\text { Cicero, Cerec } \\
\text { and Procera } \\
\text { partial crowns }\end{array}$ & $\begin{array}{l}\text { Cicero: } 74 \mu \mathrm{m} \\
\text { Cerec: } 85 \mu \mathrm{m} \\
\text { Procera: } 68 \mu \mathrm{m}\end{array}$ \\
\hline
\end{tabular}

restorative materials. ${ }^{2,3} \mathrm{~A}$ method for determining the marginal fit is to measure the marginal gap, i.e. the distance between the restoration margin and preparation margin. The methods and measurement units to determine the marginal gap of restorations are not validated. ${ }^{4}$ Furthermore, the definition of marginal fit scatters widely. To facilitate the comparison of the various studies described in the literature, Holmes ${ }^{5}$ postulated a standardised terminology to describe the various measurable marginal areas. The clinically acceptable values defined for marginal gaps vary between $20 \mu \mathrm{m}$ and $200 \mu \mathrm{m} .^{2,4,6-9}$ Table 1 provides an overview of the current studies on marginal gap formation in all-ceramic inlay restorations and partial crowns. Studies focusing only on partial crowns are currently in short supply. The goal of this in vitro study was to examine the marginal adaptation of pressed all-ceramic MOD inlay restorations and different PCR before and after adhesive cementation as well as after thermal cycling in an artificial oral environment. A standardised preparation protocol was used to prepare the teeth.

\section{MATERIAL AND METHOD}

Eighty extracted caries-free maxillary molars were used to do this study. After extraction, the teeth were stored in $0.1 \%$ thymol solution at room temperature for no longer than three months. Sixteen teeth were randomly allocated to one of the five test groups. The teeth were prepared according to a standardised protocol. Primary preparation was done with $80-\mu \mathrm{m}$ grit preparation diamonds (837KR.314.012, 847KR.314.016), while finishing was done with finer diamonds $(30-40-\mu \mathrm{m}$ grain size, 8837KR.314.012, 8847KR.314.016, 8390.204.016, Komet, Dental, Gebr. Brasseler, Lemgo, Germany).

In none of the groups was a bevel, or a retentive preparation pattern, used. The angle between the reduced cusp surface and the uncut outer tooth edge was on average 100 degrees. All internal angles were slightly rounded out (Figs 1 to 5). Preparations were done freehand by one practitioner.

Group A: MOD inlay preparation. Width and depth: $3 \mathrm{~mm}$. Overall preparation angle: 6 degrees. The proximal boxes ended 1 $\mathrm{mm}$ short of the cemento-enamel junction (basic preparation).

Group B: Basic preparation and reduction of the mesiopalatal cusp by $2 \mathrm{~mm}$ according to the anatomical shape of the occlusal surface.

Group C: Basic preparation and reduction of the mesiopalatal and distopalatal cusps by $2 \mathrm{~mm}$ according to the anatomical shape of the occlusal surface.

Group D: Basic preparation and reduction of mesiopalatal, distopalatal and distobuccal cusps by $2 \mathrm{~mm}$ according to the anatomical shape of the occlusal surface.

Group E: Basic preparation and reduction of all four cusps by $2 \mathrm{~mm}$ according to the anatomical shape of the occlusal surface. 


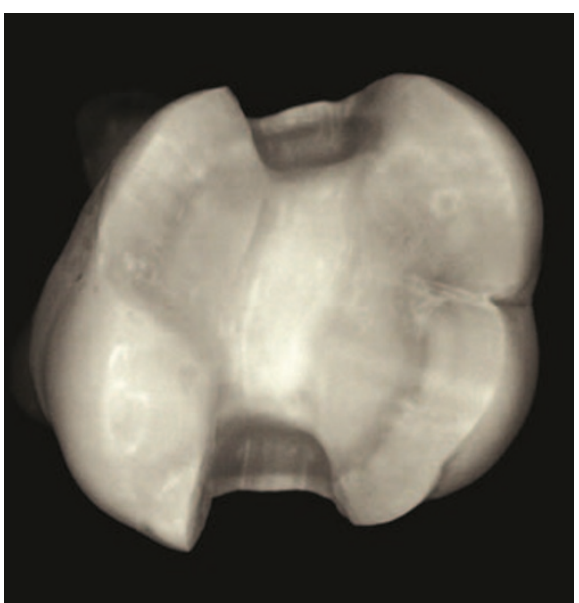

Fig. 4 Group D: Occlusal view

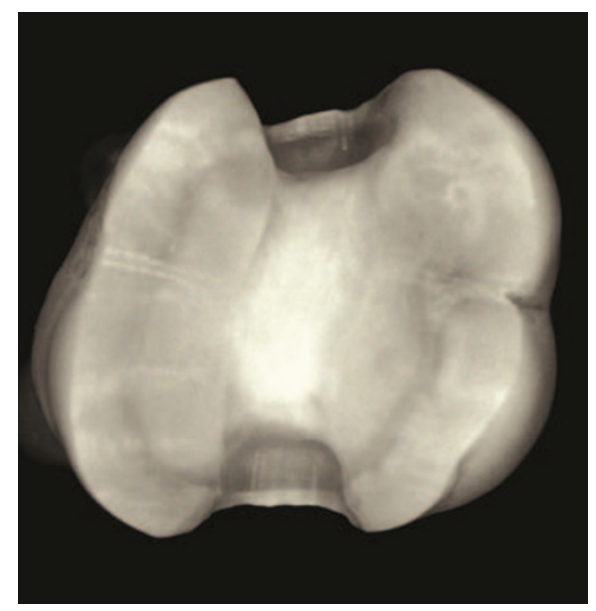

Fig. 5 Group E: Occlusal view

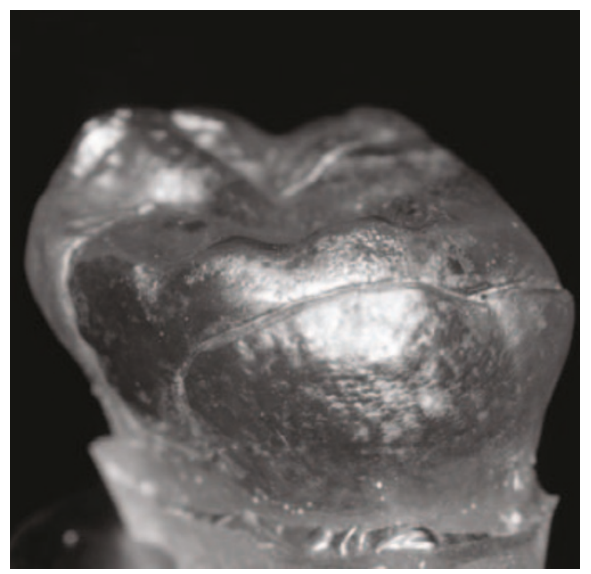

Fig. 6 Exemplary marginal gap demonstrated on a gold sputter epoxy resin replica
Impressions of the abutment teeth were taken using the double mixing technique with Permagum ${ }^{\circledR}$ Putty Soft (3M Espe, Seefeld, Germany) and Dimension ${ }^{\circledR}$ Garant L (3M Espe, Seefeld, Germany). The impressions were poured with GC FujiRock ${ }^{\circledR}$ EP (Type 4 dental stone, GC Europe, Leuven, Belgium). By the use of die hardener (Margidur $^{\circledR}$, DUS Dental-U Inc, Richmond, Canada) critical line angles along the preparation margin were strengthened and their mechanical resistance enhanced. Die spacer (Purargent $20 \mathrm{~mL}^{\circledR}$, DUS Dental-U Inc, Richmond, Canada) was applied to the cavity surfaces (approximately $10 \mu \mathrm{m}$ ) in $1.5 \mathrm{~mm}$ distance to the marginal areas. The all-ceramic restorations were fabricated by Ivoclar Vivadent AG, Schaan, Liechtenstein.

To fabricate the restorations, wax patterns were invested in Empress ${ }^{\circledR} 2$ Speed investment material (Ivoclar Vivadent AG, Schaan, Liechtenstein). The preheating cycle was carried out in a preheating furnace (Type 5636; KaVo Dental GmbH, Biberach, Germany), at a temperature of $850^{\circ} \mathrm{C}$ for 60 minutes. Subsequently, the moulds were transferred to the EP 500/V2.9 ceramic furnace (Ivoclar Vivadent AG, Schaan, Liechtenstein) and pressure filled with IPS e.max ${ }^{\circledR}$ Press VP1989/4 ingot material, at a temperature of $915^{\circ} \mathrm{C}$ for 20 minutes. After divestment and separation of the restoration, two glaze firing cycles were done in the Programat P100 furnace. For this purpose, C27688 Empress ${ }^{\circledR} 2$ glazing material (Ivoclar Vivadent AG, Schaan, Liechtenstein) was applied and fired, using a firing temperature of $770 \pm 10^{\circ} \mathrm{C}$ for six minutes. After the dental laboratory had fabricated the restorations, they were placed on the prepared teeth to check the fit using Bite Checker ${ }^{\circledR}$ (GC Europe NV, Leuven, Belgium). Interferences on the internal aspects of the ceramic restorations were removed under water cooling, using a high-speed angled handpiece and fine-grain diamonds. The ceramic restorations were adhesively cemented using Variolink ${ }^{\circledR}$ II dual-curing fine-particle hybrid composite (high viscosity) (Ivoclar Vivadent AG, Schaan, Liechtenstein).

Teeth were etched with Total Etch ${ }^{\circledR}$ and conditioned with Syntac ${ }^{\circledR}$ Classic (Ivoclar Vivadent AG, Schaan, Liechtenstein) for this purpose. The inner surfaces of the ceramic restorations were etched with IPS Ceramic etching gel ${ }^{\circledR}$ for 20 seconds and then silanized with Monobond $S^{\circledR}$ (Ivoclar-Vivadent AG, Schaan, Liechtenstein). The specimens were light-polymerized with at least a $650 \mathrm{mw} / \mathrm{cm}^{2}$ light intensity (Elipar Free Light 2; 3M ESPE, Seefeld, Germany).

Gross excess material was removed using a curette and resin pellets. Liquid Strip ${ }^{\circledR}$ glycerine gel (Ivoclar Vivadent AG, Schaan, Liechtenstein) was applied along the margins of the cement joint to prevent an oxygen inhibition layer forming during the lightcuring process. After the polymerization procedure was completed, remaining excess of cement was removed using a 15c scalpel (\#371716, Bard-Parker; Becton-Dickinson, Dr Franklin Lakes, NJ, USA), and subsequently flexible polishing discs (Sof-Lex Pop-On ${ }^{\circledR}$,
3M Medica, St. Paul, USA). To imitate the physiological mobility of teeth and biological width, an artificial periodontal membrane was applied using an anti-slip varnish (Anti-Rutsch Lack, WenkoWenslaar GmbH, Hilden, Germany). The varnish was applied in a uniform coating of 0.3-0.5 mm on the entire root surface up to 2 $\mathrm{mm}$ below the cemento-enamel junction using a disposable brush. The abutments were affixed to the specimen holders to ensure that they were facing a defined direction in the mastication simulator. The tooth axis was aligned perpendicularly to the specimen holder and the occlusal surfaces were set horizontally to the bottom of the holder. The specimens were inserted into the specimen holders up to $2 \mathrm{~mm}$ below the cemento-enamel junction using Technovit $4000^{\circledR}$ (Heraeus-Kulzer GmbH \& Co. KG, Wehrheim, Germany), a fast-curing cold-mounting three-component resin. Subsequently, the teeth were subjected to cyclic thermal mechanical loading. For this purpose, 1.2 million loading cycles were performed at a frequency of $1.6 \mathrm{~Hz}$ and a force of $98 \mathrm{~N}$, using steatite balls, which were aligned on the centre of the occlusal surface of the molars. In addition, the specimens were exposed to thermal cycling at temperatures of $5^{\circ} \mathrm{C}$ and $55^{\circ} \mathrm{C}$ (5300 cycles in total). This in vitro test simulated five years of clinical service. ${ }^{10,11}$

An impression of all the ceramic restorations was taken before and after cementation as well as after artificial aging in the mastication simulator to examine marginal adaptation. Before cementation, the partial coverage restorations were held in place with a small amount of Variolink ${ }^{\circledR}$ II Try-In paste (Ivoclar Vivadent AG, Schaan, Liechtenstein) during the impression procedure. The impressions were created with Permagum ${ }^{\circledR}$ Putty Soft (3M-Espe, Seefeld, Germany) and Dimension ${ }^{\circledR}$ Garant L (3M-Espe, Seefeld, Germany) and poured with expoxy resin (Epon 812, Sigma Chemie, Munich, Germany). The impressions were degassed in a furnace at $60^{\circ} \mathrm{C}$ for 24 hours to obtain bubble-free replicas. The epoxy resin was processed according to the manufacturer's instructions and the impressions were filled with liquid material, making sure not to incorporate any bubbles. While the epoxy resin was still liquid, the impressions were placed back into the furnace and stored at $60^{\circ} \mathrm{C}$ for 24 hours until complete polymerisation. Upon completion of the polymerisation process the replicas were removed from the moulds and the basal surfaces and margins trimmed using an acrylic cutter. The replicas were centred and mounted on prefabricated aluminium sample holders using cyanoacrylate adhesive to examine them under a stereo light microscope. The replicas were coated with a thin gold layer of $200 \AA$ in a high-vacuum sputter device (SCD 050, Bal-Tec GmbH, Witten, Ruhr, Germany) to obtain an accurate picture of the marginal gaps (Fig. 6).

Marginal gap analysis was done under a stereo light microscope from Zeiss (Stemi 2000 CS; Carl Zeiss, Jena, Germany) using 200x magnification, a 3 CCD colour video camera from Sony (Cologne, 


\begin{tabular}{|c|c|c|c|c|c|c|c|c|}
\hline $\begin{array}{l}\text { group } \\
(n=16)\end{array}$ & $\min$ & $\max$ & mean & median & iqr & geomean & se & $\mathrm{Cl}-95 \%$ \\
\hline $\begin{array}{l}\text { A: } \\
\text { Inlay }\end{array}$ & 64.9 & 103.7 & 84.3 & 84.3 & $\begin{array}{l}{[76.42 ;} \\
95.90]\end{array}$ & 83.40 & 1.04 & $\begin{array}{c}77.04- \\
90.28\end{array}$ \\
\hline $\begin{array}{l}\text { B: } \\
\text { PCR-1 } \\
\text { cusp }\end{array}$ & 58.3 & 75.5 & 67.7 & 67.7 & $\begin{array}{l}\text { [63.33; } \\
72.48]\end{array}$ & 67.53 & 1.02 & $\begin{array}{c}64.80- \\
70.37\end{array}$ \\
\hline $\begin{array}{l}\text { C: } \\
\text { PCR-2 } \\
\text { cusps }\end{array}$ & 45.5 & 74.7 & 59.8 & 59.8 & $\begin{array}{l}{[54.52 ;} \\
64.23]\end{array}$ & 59.28 & 1.04 & $\begin{array}{c}55.141- \\
63.73\end{array}$ \\
\hline $\begin{array}{l}\text { D: } \\
\text { PCR-3 } \\
\text { cusps }\end{array}$ & 41.2 & 82.5 & 57.0 & 57.0 & $\begin{array}{r}{[52.34 ;} \\
60.83]\end{array}$ & 56.36 & 1.04 & $\begin{array}{c}51.87- \\
61.24\end{array}$ \\
\hline $\begin{array}{l}\text { E: } \\
\text { PCR-4 } \\
\text { cusps }\end{array}$ & 31.6 & 65.0 & 50.5 & 50.5 & $\begin{array}{l}{[45.75 ;} \\
54.94]\end{array}$ & 49.74 & 1.05 & $\begin{array}{c}45.14- \\
54.82\end{array}$ \\
\hline
\end{tabular}

\begin{tabular}{|c|c|c|c|c|c|c|c|c|}
\hline $\begin{array}{l}\text { group } \\
(n=16)\end{array}$ & $\min$ & $\max$ & mean & median & iqr & geomean & se & $\mathrm{Cl}-95 \%$ \\
\hline $\begin{array}{l}\text { A: } \\
\text { Inlay }\end{array}$ & 72.8 & 143.5 & 104.7 & 104.7 & $\begin{array}{l}\text { [86.41; } \\
121.12]\end{array}$ & 102.89 & 1.05 & $\begin{array}{l}92.85- \\
114.01\end{array}$ \\
\hline $\begin{array}{l}\text { B: } \\
\text { PCR-1 } \\
\text { cusp }\end{array}$ & 73.1 & 115.4 & 101.5 & 101.5 & $\begin{array}{l}\text { [99.53; } \\
109.13]\end{array}$ & 100.72 & 1.03 & $\begin{array}{c}93.94- \\
107.99\end{array}$ \\
\hline $\begin{array}{l}\text { C: } \\
\text { PCR-2 } \\
\text { cusps }\end{array}$ & 75.6 & 101.6 & 93.8 & 93.8 & $\begin{array}{c}\text { [93.83; } \\
98.21]\end{array}$ & 93.45 & 1.02 & $\begin{array}{c}89.31- \\
97.78\end{array}$ \\
\hline $\begin{array}{l}\text { D: } \\
\text { PCR-3 } \\
\text { cusps }\end{array}$ & 91.9 & 116.1 & 101.7 & 101.7 & $\begin{array}{l}97.82 ; \\
105.15]\end{array}$ & 101.49 & 1.02 & $\begin{array}{l}97.96- \\
105.16\end{array}$ \\
\hline $\begin{array}{l}\text { E: } \\
\text { PCR-4 } \\
\text { cusps }\end{array}$ & 90.8 & 109.4 & 99.5 & 99.5 & $\begin{array}{l}{[95.15 ;} \\
102.75]\end{array}$ & 99.33 & 1.01 & $\begin{array}{c}96.43- \\
102.31\end{array}$ \\
\hline
\end{tabular}

\begin{tabular}{|c|c|c|c|c|c|c|c|c|}
\hline $\begin{array}{l}\text { group } \\
(n=16)\end{array}$ & $\min$ & $\max$ & mean & median & iqr & geomean & se & $\mathrm{Cl}-95 \%$ \\
\hline $\begin{array}{l}\text { A: } \\
\text { Inlay }\end{array}$ & 90.6 & 155.6 & 117.5 & 117.5 & $\begin{array}{l}{[102.52 ;} \\
136.57]\end{array}$ & 116.05 & 1.04 & $\begin{array}{c}106.42- \\
126.56\end{array}$ \\
\hline $\begin{array}{l}\text { B: } \\
\text { PCR-1 } \\
\text { cusp }\end{array}$ & 92.9 & 133.1 & 114.8 & 114.8 & $\begin{array}{l}\text { [112.94; } \\
119.35]\end{array}$ & 114.37 & 1.02 & $\begin{array}{c}108.98- \\
120.02\end{array}$ \\
\hline $\begin{array}{l}\text { C: } \\
\text { PCR-2 } \\
\text { cusps }\end{array}$ & 89.8 & 115.9 & 106.1 & 106.1 & $\begin{array}{c}\text { [103.67; } \\
110.89]\end{array}$ & 105.95 & 1.02 & $\begin{array}{c}102.48- \\
109.53\end{array}$ \\
\hline $\begin{array}{l}\text { D: } \\
\text { PCR-3 } \\
\text { cusps }\end{array}$ & 63.1 & 123.8 & 109.7 & 109.7 & $\begin{array}{c}107.52 ; \\
116.56]\end{array}$ & 108.60 & 1.04 & $\begin{array}{c}100.03- \\
117.91\end{array}$ \\
\hline $\begin{array}{l}\text { E: } \\
\text { PCR-4 } \\
\text { cusps }\end{array}$ & 99.7 & 119.2 & 108.7 & 108.7 & $\begin{array}{c}103.77 ; \\
111.91]\end{array}$ & 108.50 & 1.01 & $\begin{array}{c}105.36 \text { - } \\
111.73\end{array}$ \\
\hline
\end{tabular}

Germany) and an IBM compatible PC equipped with a Microsoft NT 4.0 operating system. Analysis 3.0 (Soft-Imaging Software GmbH, Munich, Germany) served as the image analysis programme. The marginal discrepancies were measured at intervals of $100 \mu \mathrm{m}$ around the circumference of the restoration margins. The number of points measured in each tooth varied, because human maxillary molars, which slightly differ in shape and size from each other, were used in the present study. For statistical analysis belonging measurements (between 400 and 500 points for each tooth) were averaged for each specimen. Based on these averaged marginal gap values, means and confidence intervals for assessing marginal accuracy were computed for each group and for all stages (initial, cemented, aged) of the investigation. The logarithmic transformation is an approved method for robust statistical inference on location of data that originate from skewed distributions. It leads to a stabilisation of variance estimators. Therefore, location was estimated by geometric means instead of more familiar arithmetic means. Estimation of confidence intervals and t-test were based on logarithmically transformed values also. To achieve a global level of significance $(\alpha=0.05)$ the $p$-values resulting from pairwise comparisons of unpaired t-tests (between groups) and paired t-tests (between stages) were corrected by the Bonferroni-Holm method. (Statistical software: R Development Core Team (2004). R: A language and environment for statistical computing. R Foundation for Statistical Computing, Vienna, Austria. ISBN 3-900051-00-3).

\section{RESULTS}

Marginal gap analysis of the specimens resulted in the following mean (geometrical) (CI-95\%) values before cementation, after cementation and after masticatory simulation: Group A: 83[7790] $\mu \mathrm{m}, 103[93-114] \mu \mathrm{m}$ and 116[106-127] $\mathrm{m}$; Group B: 68[65-

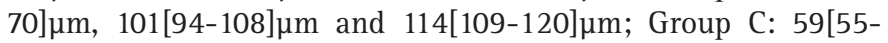

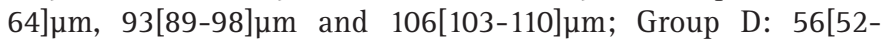
61] $\mu \mathrm{m}, \quad 102[98-105] \mu \mathrm{m}$ and $109[100-118] \mu \mathrm{m}$ and Group E: 50[45-55] $\mathrm{m}, 99[96-102] \mu \mathrm{m}$ and 109[105-112] $\mu \mathrm{m}$. Descriptive statistics are displayed in Tables 2-4 along with geometric means and confidence limits, see also Figure 7.

Before cementation, the mean (geometrical) marginal gap width consistently decreased, as the dimensions of the restorations increased from Group A to Group E (Table 2). Group A had significantly higher marginal gap values than group $B(p=0.017)$ and the other groups ( $\mathrm{p}<0.0001)$. Group E (PCR-4 cusps) showed significant lower marginal gap values than Group B (PCR-1 cusp) $(p=0.0002)$.

After the cementation of the ceramic restorations, the groups A, B, C, D and E did not significantly differ from each other ( $p>0.05)$ (Table 3). Cementation increased the marginal gap in groups B-E significantly $(p<0.00001)$, not significantly in group A ( $p=0.059)$.

After masticatory simulation the marginal gap values of all groups did not demonstrate any significant differences ( $p>0.05)$ (Table 4). Compared to marginal gap values after cementation masticatory loading led to further decrease of marginal accuracy in Group B ( $p=0.029)$ and C ( $=0.026)$ significantly, not statistically significant in the remaining groups $(p>0.05)$.

\section{DISCUSSION}

In vitro and in vivo studies that have examined the width of the marginal gap of all-ceramic partial coverage restorations are in short supply. ${ }^{12-14}$ Direct comparisons between published studies are very limited due to the differences in the study set-ups and statistical analyses.

The dental laboratory procedures, the manual skills and the experience of the dental technician have a decisive influence on the marginal gap width. Consequently, all restorations employed in the present study were fabricated by the same master technician to ensure that these factors did not change for the individual test groups. The fine-particle hybrid luting composite Variolink ${ }^{\circledR}$ II (Ivoclar Vivadent, AG, Schaan, Liechtenstein) was used to cement the restorations because this composite has been reported to have produced the best marginal quality in relevant studies. ${ }^{15-17}$ Replica technology was used to monitor the changes in marginal gap width in the course of the investigation. The replica technique is less costly and time consuming for the user to create test specimens than other methods (eg cross section preparation technique). However, the replica technique cannot be used to examine the microleakage and disintegration of luting composite in the cement joint.

The marginal gaps measured for all five test groups before cementation, after cementation and after artificial aging were on average in the range of $120 \mu \mathrm{m}$, a value defined as clinically acceptable. ${ }^{7}$ After cementation, the cement joints of the 
restorations were on average thicker than the $50-100 \mu \mathrm{m}$ described by Molin ${ }^{18}$ in 1996 as being ideal for achieving a strong bond between the ceramic and resin composite.

Before cementation, significantly larger mean cement joints were measured in the specimen that were restored with conventional inlay restorations (Group A) than in the ones that were restored with modified PCR. The mean thickness of the cement joints gradually decreased as the number of cusps included in the restorations increased. The smallest mean cement joint was measured in PCR that involved four cusps (Group E). The height of the occlusal isthmus was lower in the partial coverage preparations than in the inlay preparations due to the reduction of the cusps. The reduced height of the isthmus may have decreased the risk of jamming, or inappropriately high friction during insertion. It remains to be examined whether the marginal fit can be improved by increasing the divergence of the overall preparation angle $\left(>6^{\circ}\right)$ in the occlusal box. The literature currently available does not include any data on this issue. A study by Denissen ${ }^{12}$ also examined the marginal fit of all-ceramic PCR before cementation. This study used an experimental preparation design. The molars were prepared with deep gingival chamfers in the proximal boxes and around the functional cusps. The non-functional cusps were prepared with broad bevels. The marginal gap of 25 partial crowns, which were fabricated with different CAD/CAM systems, was measured on stone dies prior to cementation. The mean marginal gaps of the Cicero, Cerec and Procera onlays on the stone dies were $74 \mu \mathrm{m}, 85 \mu \mathrm{m}$ and $68 \mu \mathrm{m}$ respectively. These values are slightly higher than the mean marginal gaps measured for Group B (68 $\mu \mathrm{m}), \mathrm{C}(60 \mu \mathrm{m}), \mathrm{D}(57 \mu \mathrm{m})$ and $\mathrm{E}(51 \mu \mathrm{m})$ of the present study.

Denissen ${ }^{12}$ reported a mean cement width of $81 \mu \mathrm{m}$ after the partial crowns had been cemented in place. This value is lower than the marginal gap measured after the cementation of the partial coverage restorations used in the present study. Gemalmaz ${ }^{19}$ also described an increase in the marginal gap of ceramic inlays after cementation. In the present study, a significant increase in marginal gap width was observed for all partial coverage restorations after adhesive cementation. The lowest increase in mean marginal gap width after cementation was recorded for Group A (20 $\mu \mathrm{m})$, followed by Group B (34 $\mu \mathrm{m}), \mathrm{C}(34 \mu \mathrm{m}), \mathrm{D}(45 \mu \mathrm{m})$ and $\mathrm{E}(49 \mu \mathrm{m})$. Basically, the increase in marginal gap width is caused by the volume requirement of the luting cement, depending on particle size, flow properties, and consistency. ${ }^{15,16}$ Hence, the large initial gap, which facilitates the flowing off of luting material during the cementation process, may explain why the cement width increased to a lesser degree in Group A than it did in the other groups. Conversely, Group E, which showed the best initial fit, produced the largest increase in marginal gap after cementation. The good initial fit and the size of the restoration surface may have diminished the capability of the luting composite to flow off and consequently may have been conducive to increasing the cement width of this group. After masticatory simulation and thermal cycling, a significant increase of the marginal gap was observed for Group B ( $p=0.029)$ and C ( $p=0.026)$ only. Nevertheless, a trend towards decrease of marginal accuracy after fatigue was demonstrated in all groups. Numerous in vivo studies have provided evidence that the marginal quality of ceramic restorations tends to deteriorate over the years after adhesive cementation. ${ }^{20-24}$ The increase in marginal gap width after thermal cycling and artificial aging may be attributed to hydrolytic and mechanical stresses. The luting composite may absorb water and the resultant expansion in volume may lead to an increase in marginal gap width. However, the median marginal gaps of the test groups were slightly below the clinically acceptable marginal gap of $120 \mu^{7}$ even after thermal cycling and masticatory simulation.

\section{CONCLUSIONS}

The results of this in vitro study showed that the press ceramic IPS e.max ${ }^{\circledR}$ Press (VP 1989) can be used to fabricate inlays and partial crowns which meet the requirements in terms of a clinically acceptable marginal gap, irrespective of the preparation design used. However, the preparation design and dimensions of the restorations appeared to affect the initial marginal fit and flowing off of luting material during the cementation process. The factors responsible for these findings require further substantiation. A clinical trial on the new preparation designs and materials is desirable.

The authors would like to acknowledge M. Hans-Peter Foser, Master Dental Technician, Ivoclar-Vivadent AG, Schaan, FL, for his effort in the fabrication of the ceramic restorations for this study.

1. Anusavice KJ. Degradability of dental ceramics. Adv Dent Res 1992: 6: 82-89.

2. Rehberg H J. Exact marginal accuracy - what does that mean? Dtsch Zahnärztl Z 1971; 26: 696-699.

3. Noack M J. Adaptation of composite-, glass-ceramic- and ceramic-inlays. Dtsch ZahnärztlZ 1994: 49:873-878.

4. Kerschbaum T. Standardized margin of the restoration? - Results from the clinical point of view. In Walther W (ed) Qualitätssicherung in der Zahnheilkunde. pp 19-45. Heidelberg: Hüthig $\mathrm{GmbH}, 1995$.

5. Holmes J R, Bayne S C, Holland G A et al. Considerations in measurement of marginal fit. J Prosthet Dent 1989; 62: 405-408.

6. Dreyer Jorgensen K. Testing results of dental casting techniques. Dtsch Zahnäztl Z1958; 13: 461-649.

7. McLean J W, Von Fraunhofer J A. The estimation of cement film thickness by an in vivo technique. Br Dent J 1971; 131: 107-111.

8. Marxkors R. Marginal accuracy of gold crowns. Dtsch Zahnärzt/Z 1980; 35: 913-915.

9. Spiekermann H. Crown restorations and periodontal tissue response. In Lange D E (ed) Parodontologie, Implantologie und Prothetik im Brennpunkt von Praxis und Wissenschaft.pp 209-233. Berlin: Quintessenz, 1985.

10. Delong $R$, Douglas W H. Devlopment of an artificial oral environment for the testing of dental restoratives: bi-axial force and movement control. J Dent Res 1983; 62:32-36.

11. Sakaguchi RL, Douglas WH, De Long $R$ et al. The wear of a posterior composite in an artificial mouth: a clinical correlation. Dent Mater 1986; 2: 235-240.

12. Denissen H, Dozic A, Van Der Zel J, M V W. Marginal fit and short-term clinical performance of porcelain-veneered CICERO, CEREC and PROCERA onlays. J Prosthet Dent 2000: 84: 506-513.

13. Hürzeler M, Zimmermann E, Mörmann W H. The marginal adaptation of mechanically produced onlays in vitro. Schweiz Monatsschr Zahnmed 1990; 100: 715-720.

14. Schäfers $F$, Järschke J, Meyer G. Accuracy of fit of different all-ceramic procedures. ZWR 1994: 103: 686-689.

15. Lang $R$, Rosentritt $M$, Behr $M$, et al. The influence of modified glass ionomer cement, polyacid modified composite- and composite resin on the marginal accuracy of ceramic inlays. Dtsch Zahnärztl Z2000; 55: 540-543.

16. Gemalmaz D, Ozcan M, Alkumru H N. A clinical evaluation of ceramic inlays bonded with different luting agents. J Adhes Dent 2001; 3:273-283.

17. Lafuente J D, Chaves A, Carmiol R. Bond strength of dual-cured resin cements to human teeth. J Esthet Dent 2000; 12: 105-110.

18. Molin M K, Karlsson S L, Kristiansen M S. Influence of film thickness on joint bend strength of a ceramic/resin composite joint. Dent Mater 1996; 12: 245-249.

19. Gemalmaz $D$, Özcan $M$, Yoruc $A B$, et al. Marginal adaptation of a sintered ceramic inlay system before and after cementation. J Oral Rehabil 1997; 24: 646-651.

20. Felden A, Schmalz G, Federlin M, et al. Retrospective clinical study and survival analysis on partial ceramic crowns: results up to 7 years. Clin Oral Invest 2000; 4: 199-205.

21. Isenberg B P, Essig M E, Leinfelder K F. Three-year clinical evaluation of CAD/CAM restorations. J Esthet Dent 1992; 4: 173-176.

22. Krämer $N$, Frankenberger $R$, Pelka $M$, et al. IPS EMPRESS inlays and onlays after four years - a clinical study. J Dent 1999; 27: 325-331.

23. Otto $T_{1}$ De Nisco $\mathrm{S}$. Computer-aided direct ceramic restorations: a 10-year prospective clinical study of Cerec CAD/CAM inlays and onlays. Int J Prosthodont 2002; 15: 122-128.

24. Felden A, Schmalz G, Hiller K-A. Retrospective clinical investigation and survival analysis on ceramic inlays and partial ceramic crowns: results up to 7 years. Clin Oral Invest 1998; 2: 161-167.

25. Hahn R. Experimental investigations of reproducible fitting accuracy of ceramic inserts. Dtsch Zahnärzt/Z 1990; 45: 653-656.

26. Siervo $S$, Bandettini $B$, Siervo $P$, et al. The CELAY system: a comparison of the fit of direct and indirect fabrication technique. Int J Prosthodont 1994: 7: 434-439.

27. Siervo S, Pampalone A, Siervo P, et al. Where is the gap? Machinable ceramic systems and conventional laboratory restorations at a glance. Quintessence Int 1994; 25: 773-779.

28. Mörmann W H, Schug J. Grinding precision and accuracy of fit aof CEREC 2 CAD/CIM inlays. J Amer Dent Assoc 1997; 128: 47-53.

29. Sturdevant J R, Bayne S C, Heymann H O. Margin gap size of ceramic inlays using second-generation CAD/CAM equipment. J Esthet Dent 1999; 11: 206-214. 